\title{
Toxicity of Glucosinolate Degradation Products from Brassica napus Seed Meal Toward Aphanomyces euteiches f. sp. pisi
}

\author{
U. Smolinska, M. J. Morra, G. R. Knudsen, and P. D. Brown
}

Department of Plant, Soil, and Entomological Sciences, University of Idaho, Moscow, ID 83844-2339.

Current address of U. Smolinska: Research Institute of Vegetable Crops, Konstytucji 3 Maja 1/3, 96-100 Skierniewice, Poland. Accepted for publication 4 October 1996.

\begin{abstract}
Smolinska, U., Morra, M. J., Knudsen, G. R., and Brown, P. D. 1997. Toxicity of glucosinolate degradation products from Brassica napus seed meal toward Aphanomyces euteiches f. sp. pisi. Phytopathology 87:77-82.

Brassica tissues are potentially useful in the control of Aphanomyces root rot of peas (Pisum sativum), but identity of the responsible compounds and specific impacts of those compounds on the pathogen's infection potential remain uncertain. Brassica napus seed meals and water extracts from these meals were used to determine the effect of glucosinolate hydrolysis products on Aphanomyces euteiches f. sp. pisi. B. napus meal ('Dwarf Essex') containing glucosinolates and intact myrosinase, the enzyme responsible for glucosinolate hydrolysis, completely inhibited infection by A. euteiches f. sp. pisi oospores. Water extracts from

('Stonewall') produced little disease reduction and had less impact on mycelial growth. Gas chromatographic analysis of Brassica tissues and water extracts confirmed that glucosinolates remained in autoclaved 'Dwarf Essex' meal and that 'Stonewall' meal contained low glucosinolate concentrations. 5-Vinyloxazolidine-2-thione was identified by mass spectrometry as a dominant glucosinolate hydrolysis product in aqueous extracts of the inhibitory meal. Bioassays conducted with aqueous solutions of this compound reduced mycelial growth, but not to the extent of those from intact 'Dwarf Essex' meal. Water-soluble compounds produced from the hydrolysis of glucosinolates in B. napus tissues reduced A. euteiches oospore infection and inhibited mycelial growth, thus, demonstrating potential utility of Brassica species in the control of $\mathrm{A}$. e euteiches.
\end{abstract} this meal, likewise, severely inhibited infection by oospores, as well as mycelial growth. Extracts from autoclaved 'Dwarf Essex' meal, in which myrosinase was denatured, and a low glucosinolate B. napus variety
Additional keywords: allelochemicals, rapeseed meal.
Glucosinolates, organic anions containing $\beta$-D-thioglucose and sulfonated oxime moieties, are present in Brassicaceae (Cruciferae) tissues. Hydrolysis by the enzyme myrosinase (thioglucoside glucohydrolase, EC 3.2.3.1) releases numerous compounds including isothiocyanates, thiocyanate ion, nitriles, and epithionitriles $(5,19,34,35)$. The types of compounds produced are specific to the respective glucosinolates present in the tissue and conditions under which hydrolysis occurs $(12,21)$.

It has been demonstrated that Brassicaceae residues are fungicidal $(1,4,11,36)$ and that soil amendment with cruciferous plants reduces the incidence of Aphanomyces root rot of pea $(4,26)$. The responsible mechanism for this toxicity is unclear, but the detrimental effect of cruciferous tissues on other microorganisms has been attributed mainly to volatile degradation products of glucosinolates released from these plants $(7,9,10,19,20)$. For example, volatile compounds from macerated Brassica root tissue inhibited the fungal pathogen of wheat, Gaeumannomyces graminis (1). The glucosinolate product allyl isothiocyanate released from macerated cabbage tissues proved to be toxic toward Peronospora parasitica (13), and isothiocyanates and aldehydes in solarized soil amended with cabbage residues correlated with the reduction of Pythium ultimum and Sclerotium rolfsii propagules (11).

Less is known about the role of low volatility, water-soluble glucosinolate degradation products in disease suppression, but these and other water-soluble secondary compounds have been implicated in allelopathic interactions $(3,22,23,31)$. Aqueous extracts of cabbage (Brassica oleraceae) did not suppress Aphanomyces root rot of peas (28), nor did aqueous extracts inhibit

Corresponding author: M. J. Morra; E-mail address: mmorra@uidaho.edu

Publication no. P-1996-1125-04R

(C) 1997 The American Phytopathological Society growth of Propionibacterium (32). However, fungal inhibition by aqueous extracts from Brassica plants has been observed $(27,36)$. Both water-soluble and volatile glucosinolate degradation products may, therefore, be involved in disease suppression and may be useful in the biological control of plant pathogens. Effects will depend on the target organism and the particular glucosinolate profile in the plant tissue.

Our objectives were to compare antifungal activities of rapeseed meal with that of aqueous rapeseed meal extracts toward Aphanomyces euteiches Drechs. f. sp. pisi W.F. Pfender \& D.J. Hagedorn, and to test the hypothesis that glucosinolate degradation products, particularly those that are water-soluble, were responsible for fungicidal activity.

\section{MATERIALS AND METHODS}

Organisms and plant tissues. A. euteiches f. sp. pisi obtained from W. J. Kaiser (USDA-ARS, Pullman, WA) was maintained on Difco potato dextrose agar (PDA) (Difco Laboratories, Detroit) at $4^{\circ} \mathrm{C}$. The pea (Pisum sativum L.) cultivar Columbia was used in all bioassay experiments, and defatted rapeseed meal from two cultivars of Brassica napus L. served as the source of glucosinolates. Defatted seed meal consists of high protein seed tissue remaining after oil is expressed (30). Defatted seed meal from the Dwarf Essex cultivar contains high glucosinolate concentrations, whereas meal from the Stonewall cultivar contains substantially lower glucosinolate concentrations (Table 1). 'Dwarf Essex' meal was also treated using two methods to reduce concentrations of glucosinolate hydrolysis products. The first method was to autoclave the meal at $121^{\circ} \mathrm{C}$ for $20 \mathrm{~min}$ to denature myrosinase and prevent catalysis of the glucosinolate hydrolysis reaction. An alternative treatment was to incubate the meal for $48 \mathrm{~h}$ in water $(3: 1, w t / w t)$ prior to use in bioassays to promote glucosinolate 
hydrolysis. Volatile and unstable glucosinolate hydrolysis products were allowed to dissipate during the incubation period, and water-soluble glucosinolate products were removed at the end of incubation by washing the meal under vacuum with deionized water. Thus, four treatments were created: intact 'Dwarf Essex' meal containing its full compliment of glucosinolates and myrosinase, and three control tissues for comparison consisting of low glucosinolate 'Stonewall'; autoclaved 'Dwarf Essex' with glucosinolates, but denatured myrosinase; and 'Dwarf Essex' meal in which glucosinolates had been hydrolyzed and the volatile products removed (Table 1).

Analysis of glucosinolates and glucosinolate hydrolysis products. Glucosinolate measurement was performed using a gas chromatographic (GC) method similar to that recommended by the Canadian Grain Commission $(3,6)$. Glucosinolates were extracted with methanol from $0.2 \mathrm{~g}$ of plant tissue. The extract was placed on columns of DEAE Sephadex A-25 (Sigma Chemical Co., St. Louis) that were first treated with $6 \mathrm{M}$ imidazole in $5 \mathrm{M}$ formic acid and rinsed with water. Other compounds were separated from the sample in rinse steps using $67 \%$ methanol and water. Glucosinolates were desulfated overnight, removed from the columns using $60 \%$ methanol, and silylated in acetone. Silylated derivatives were separated and identified using a Hewlett-Packard 5890 series II GC equipped with a 5972 quadrupole mass selective detector (MSD) (Hewlett-Packard Co., Palo Alto, CA). GCMSD operating conditions have been previously described (3) and included the following: injector $260^{\circ} \mathrm{C}$; interface $320^{\circ} \mathrm{C}$; initial oven temperature $130^{\circ} \mathrm{C}$ for $1 \mathrm{~min}$, ramped $15^{\circ} / \mathrm{min}$ to $320^{\circ} \mathrm{C}$ and held for $10 \mathrm{~min}$; purge (splitless injection) $0.5 \mathrm{~min}$; He flow of $1.14 \mathrm{ml} / \mathrm{min}$; emission at $50 \mu \mathrm{A}$; repeller at $30 \mathrm{~V}$; and scan range of $\mathrm{m} / \mathrm{z}$ 25-470. The column coating was $5 \%$ phenyl-substituted methylpolysiloxane (HP-5MS; $30 \mathrm{~m}, 0.25 \mathrm{~mm}$ inside diameter, and $0.250-\mu \mathrm{m}$ film).

Meal samples were extracted with dichloromethane $\left(\mathrm{CH}_{2} \mathrm{Cl}_{2}\right)$ 20 min after wetting to determine an overall profile of glucosinolate degradation products. For most glucosinolate degradation products, analysis was done according to procedures already described (2) with a slight modification of temperature programming for the $\mathrm{GC}$ as follows: injector $220^{\circ} \mathrm{C}$, flame ionization detector (FID) $280^{\circ} \mathrm{C}$, initial oven temperature $36^{\circ} \mathrm{C}$ for $3 \mathrm{~min}$, first ramp $20^{\circ} / \mathrm{min}$ to $96^{\circ} \mathrm{C}$, second $\operatorname{ramp} 8 \% \mathrm{~min}$ to $216^{\circ} \mathrm{C}$, and third ramp $16^{\circ} / \mathrm{min}$ to $280^{\circ} \mathrm{C}$ and held for $7 \mathrm{~min}$. In a few cases in which peak identification on FID chromatograms was difficult, relative product quantities were determined by direct comparison with phenyl isothiocyanate (internal standard) using GC-MSD chromatograms. To determine water-soluble products (except $\mathrm{SCN}^{-}$) in aqueous extracts, $1 \mathrm{ml}$ of $0.4 \mathrm{M} \mathrm{CaCl}_{2}$ was added to a 4-ml aliquot of the $1,000 \mathrm{ml}$ of extract (described below). Eight milliliters of

TABLE 1. Glucosinolate concentrations ( $\mu \mathrm{mol} / \mathrm{g}$ of meal) in different types of Brassica napus meal

\begin{tabular}{lcccc}
\hline & $\begin{array}{c}\text { Intact } \\
\text { 'Dwarf } \\
\text { Essex'w }\end{array}$ & $\begin{array}{c}\text { Autoclaved } \\
\text { 'Dwarf } \\
\text { Essex'x }\end{array}$ & $\begin{array}{c}\text { Hydrolyzed } \\
\text { 'Dwarf } \\
\text { Essex'y }\end{array}$ & $\begin{array}{c}\text { Intact } \\
\text { 'Stonewall'z }\end{array}$ \\
\hline Allyl & 0.3 & 0.2 & 0.0 & $<0.1$ \\
3-Butenyl & 37.9 & 36.4 & 0.1 & 1.3 \\
4-Pentenyl & 12.8 & 12.5 & 0.0 & 0.8 \\
2-OH-3-butenyl & 83.2 & 80.4 & 0.0 & 2.6 \\
2-OH-4-pentenyl & 6.7 & 6.5 & 0.0 & 0.2 \\
4-Methylthiobutyl & 0.9 & 1.0 & 0.0 & $<0.1$ \\
Phenylethyl & 2.5 & 1.9 & 0.0 & $<0.1$ \\
5-Methylthiopentyl & 0.7 & 0.9 & 0.0 & $<0.1$ \\
3-Indolylmethyl & 0.2 & 0.0 & 0.0 & 0.0 \\
4-OH-3-indolylmethyl & 5.1 & 4.0 & 0.0 & 2.5 \\
\hline
\end{tabular}

${ }^{\mathrm{w}}$ Meal contained glucosinolates and functional myrosinase enzyme responsible for glucosinolate hydrolysis.

x Myrosinase was denatured by autoclaving.

y Glucosinolates hydrolyzed prior to analytical measurement.

${ }^{\mathrm{z}}$ Low glucosinolate containing variety.
$\mathrm{CH}_{2} \mathrm{Cl}_{2}$ were then added, samples were placed on a shaker for 15 min, and analysis conducted in the same manner as for other extracts. All values presented for chemical analyses are averages of triplicate replications.

Identification of compounds was verified using GC-MSD. Operating conditions were as previously described (3) and included the following: injector $225^{\circ} \mathrm{C}$, interface $280^{\circ} \mathrm{C}$, initial oven temperature $36^{\circ} \mathrm{C}$ for $2 \mathrm{~min}$, first ramp $15^{\circ} / \mathrm{min}$ to $96^{\circ} \mathrm{C}$, second ramp $8^{\circ} / \mathrm{min}$ to $216^{\circ} \mathrm{C}$, third ramp $18^{\circ} / \mathrm{min}$ to $270^{\circ} \mathrm{C}$ and held for $4 \mathrm{~min}$, purge $0.5 \mathrm{~min}$, He flow of $1.14 \mathrm{ml} / \mathrm{min}$, emission at $50 \mu \mathrm{A}$, repeller at $30 \mathrm{~V}$, and scan range of $m / z$ 30-280. The column was an HP5MS (30 m, $0.25 \mathrm{~mm}$ inside diameter, $0.250-\mu \mathrm{m}$ film).

Oospore infection in the presence of $B$. napus meal. Bioassays were conducted in a growth chamber at $20^{\circ} \mathrm{C}$ using sand amended with $1 \%$ rapeseed meal (wt/wt), except in the case of the control, which contained only sand. The amended or unamended sand $(33 \mathrm{~g})$ was poured into $45-\mathrm{ml}$ plastic tubes and wetted with $10 \mathrm{ml}$ of water. Oospores were produced on a V8 juice medium (8), added as a suspension in an amount corresponding to 100 oospores/g of sand, and covered with an additional 2 to $3 \mathrm{~mm}$ of sand. The following day, pea seeds were placed into the tubes and lightly covered with additional sand. The tubes were top-watered for 28 days, at which time the plants were removed and the roots washed and rated on a 0 to 4 scale for Aphanomyces root rot (29). Each treatment was performed with 20 replicate tubes, and the entire experiment was repeated twice. Wet weights of whole plants and their respective root systems were obtained for each plant.

Oospore infection in the presence of aqueous extracts from B. napus meal. Extracts of water-soluble glucosinolate products were obtained at $25 \pm 3^{\circ} \mathrm{C}$ by adding $1,000 \mathrm{ml}$ of water to $30 \mathrm{~g}$ of

TABLE 2. Glucosinolate degradation products ( $\mu \mathrm{mol} / \mathrm{g}$ of meal) in Brassica napus meal

\begin{tabular}{|c|c|c|c|}
\hline $\begin{array}{l}\text { Glucosinolate degradation } \\
\text { products }^{\mathrm{u}}\end{array}$ & $\begin{array}{l}\text { Intact } \\
\text { 'Dwarf } \\
\text { Essex'v }\end{array}$ & $\begin{array}{c}\text { Autoclaved } \\
\text { 'Dwarf } \\
\text { Essex'w }\end{array}$ & $\begin{array}{c}\text { Hydrolyzed } \\
\text { 'Dwarf } \\
\text { Essex'x }\end{array}$ \\
\hline 3-Butenyl CN & 0.17 & 0.10 & 0.00 \\
\hline 1-Methylethyl ITC & Trace $^{\mathrm{y}}$ & 0.00 & 0.00 \\
\hline 4-Pentenyl CN & 0.04 & Trace & 0.00 \\
\hline Allyl ITC & 0.02 & Trace & Trace \\
\hline 1-Methylpropyl ITC & 0.01 & 0.00 & 0.00 \\
\hline 2-Hydroxy-3-butenyl CN & 0.57 & 0.24 & 0.25 \\
\hline 3-Butenyl ITC & 4.16 & Trace & 0.25 \\
\hline Butyl ITC & 0.00 & Trace & Trace \\
\hline 2-Methylbutyl ITC & 0.00 & 0.01 & Trace \\
\hline 4-Pentenyl ITC & 1.49 & 0.00 & 0.01 \\
\hline 3-Butenylepithio $\mathrm{CN}$ & 1.01 & 0.00 & 0.10 \\
\hline 4-Methylpentyl ITC & 0.02 & 0.00 & 0.00 \\
\hline 5-Hexenyl ITC & Trace & 0.00 & 0.00 \\
\hline 2-Hydroxy-3-butenylepi CN1 & 0.79 & 0.00 & 0.07 \\
\hline Phenylethyl CN & 0.13 & 0.01 & 0.04 \\
\hline 2-Hydroxy-3-butenylepi CN2 & 0.84 & 0.00 & 0.07 \\
\hline 4-Pentenylepithio CN & 0.04 & 0.00 & 0.04 \\
\hline 5-Methylhexyl ITC & Trace & 0.00 & 0.00 \\
\hline 5-Methylthiopentyl CN & 0.01 & 0.00 & 0.00 \\
\hline 4-Methylthiobutyl ITC & 0.09 & 0.00 & 0.00 \\
\hline Phenylethyl ITC & 0.65 & Trace & 0.07 \\
\hline 5-Vinyl OZT & 3.94 & 0.59 & 2.83 \\
\hline 5-Methylthiopentyl ITC & 0.05 & 0.00 & 0.00 \\
\hline 5-Allyl OZT & 0.67 & 0.00 & 0.36 \\
\hline Dimethylsulfone ${ }^{z}$ & Trace & Trace & 0.00 \\
\hline
\end{tabular}

${ }^{\mathrm{u}} \mathrm{CN}=$ nitrile, $\mathrm{ITC}=$ isothiocyanate, and OZT $=$ oxazolidine-2-thione.

${ }^{v}$ Meal contained glucosinolates and functional myrosinase enzyme responsible for glucosinolate hydrolysis.

w Myrosinase was denatured by autoclaving.

${ }^{x}$ Glucosinolates hydrolyzed and meal washed prior to product extraction.

y Trace $<0.01 \mu \mathrm{mol} / \mathrm{g}$ meal and/or detected with gas chromatographic-mass selective detector.

$\mathrm{z}$ Tentative identification and, in this case, not necessarily a glucosinolate degradation product. 
B. napus meal and mixing every 1 to $2 \mathrm{~h}$. After $24 \mathrm{~h}$, a clear aqueous extract was obtained by centrifuging the mixture. Bioassays to determine infection of $P$. sativum by $A$. euteiches oospores were conducted in a growth chamber at $20^{\circ} \mathrm{C}$ using sand in the same manner as those involving meal amendment. Sand (33 g) was poured into $45-\mathrm{ml}$ plastic tubes and wetted with $10 \mathrm{ml}$ of the meal extract. Oospores were added as a suspension in an amount corresponding to 100 oospores/g of sand and covered with an additional 2 to $3 \mathrm{~mm}$ of sand. The following day, pea seeds were placed into the tubes and lightly covered with additional sand. The tubes were top-watered for 18 days, at which time plants were removed and the roots washed and rated on a 0 to 4 scale for Aphanomyces root rot (29). Each treatment consisted of 20 replications, and the entire experiment was repeated. Wet weights of whole plants and their respective root systems were obtained for each plant.

Mycelial growth in the presence of water extracts from $B$. napus meal. Aqueous extracts of $B$. napus meal were obtained as previously described. This extract and a 50\% dilution of the extract were used in place of water for the preparation of a $50 \%$ corn meal agar medium (CMA Y2). Since the agar medium was to be autoclaved, water extracts obtained from 'Dwarf Essex' meal were autoclaved to check for compound stability. After autoclaving the media, discs of the fungus from 5- to 7-day-old colonies were placed in the center of petri plates. Radial growth was measured daily on plates incubated for 5 days at $25^{\circ} \mathrm{C}$. Each treatment consisted of three or four replications, and the entire experiment was performed twice.

Mycelial growth in the presence of 5-vinyloxazolidine-2thione. Glucosinolate analyses showed 2-hydroxy-3-butenyl to be the predominant glucosinolate in B. napus meal (Table 1). The hydrolytic product of this glucosinolate is an isothiocyanate that spontaneously cyclizes to the water-soluble compound 5-vinyloxazolidine-2-thione. This compound was predicted as the major glucosinolate product in meal extracts and, therefore, used in bioassays to determine its biological activity. 5-Vinyloxazolidine-2thione (Lancaster Synthesis Ltd., Windham, $\mathrm{NH}$ ) was dissolved in distilled water, passed through a $0.2-\mu \mathrm{m}$ membrane filter (Nalge Co., Rochester, NY), and added to melted CMA Y2 agar to achieve a final concentration of $1.48 \mu \mathrm{mol} / \mathrm{cm}^{3}$. This concentration of 5-vinyloxazolidine-2-thione was identical to that present in the CMA Y2 agar prepared with aqueous extracts from B. napus meal. A 5-mm disc of A. euteiches was placed in the center of the

TABLE 3. Concentrations ( $\mu \mathrm{mol} / \mathrm{g}$ of meal) of glucosinolate degradation products in aqueous extracts of Brassica napus meal

\begin{tabular}{|c|c|c|c|c|}
\hline $\begin{array}{l}\text { Glucosinolate degradation } \\
\text { products }^{\mathrm{u}}\end{array}$ & $\begin{array}{l}\text { Extract } \\
\text { from intact } \\
\text { 'Dwarf } \\
\text { Essex'v }\end{array}$ & $\begin{array}{c}\text { Extract } \\
\text { from } \\
\text { autoclaved } \\
\text { 'Dwarf } \\
\text { Essex'w }\end{array}$ & $\begin{array}{l}\text { Extract } \\
\text { from } \\
\text { 'Stone } \\
\text { wall'x }\end{array}$ & $\begin{array}{c}\text { Autoclaved } \\
\text { extract } \\
\text { from intact } \\
\text { 'Dwarf } \\
\text { Essex'y }\end{array}$ \\
\hline 3-Butenyl CN & 0.10 & 0.06 & 0.00 & 0.04 \\
\hline 2-Hydroxy-3-butenyl CN & 0.56 & 0.30 & 0.01 & 0.53 \\
\hline 3-Butenyl ITC & 0.17 & 0.00 & 0.02 & Trace $^{\mathrm{z}}$ \\
\hline 3-Butenylepithio $\mathrm{CN}$ & 1.29 & 0.00 & 0.06 & 0.98 \\
\hline 2-Hydroxy-3-butenylepi CN1 & 0.71 & 0.00 & 0.01 & 0.51 \\
\hline 2-Hydroxy-3-butenylepi CN2 & 1.02 & 0.00 & 0.00 & 0.93 \\
\hline 5-Vinyl OZT & 49.48 & 1.06 & 1.80 & 46.35 \\
\hline 5-Allyl OZT & 4.90 & 0.00 & 0.00 & 4.46 \\
\hline 4-Methylsulfinylbutyl ITC & $\sim 0.42$ & 0.00 & 0.00 & $\sim 0.07$ \\
\hline 5-Methylsulfinylpentyl ITC & $\sim 0.39$ & 0.00 & 0.00 & $\sim 0.09$ \\
\hline
\end{tabular}

" $\mathrm{CN}=$ nitrile, $\mathrm{ITC}=$ isothiocyanates, and OZT $=$ oxazolidine-2-thione.

${ }^{v}$ Meal from which extract was obtained contained glucosinolates and functional myrosinase enzyme responsible for glucosinolate hydrolysis.

${ }^{w}$ Myrosinase in meal was denatured by autoclaving prior to product extraction and analytical measurement.

${ }^{x}$ Glucosinolates hydrolyzed and meal washed prior to product extraction.

y Aqueous extract obtained from meal containing glucosinolates and functional myrosinase was autoclaved.

$\mathrm{z}$ Trace $<0.05 \mu \mathrm{mol} / \mathrm{g}$ of meal. petri plate containing CMA Y2 prepared with 5-vinyloxazolidine2-thione, and the plates were incubated under lighted conditions at $25^{\circ} \mathrm{C}$. The diameter of the colonies was measured daily and compared with control plates containing CMA Y2 without 5-vinyloxazolidine-2-thione. Each treatment was replicated four times, and the experiment was repeated.

\section{RESULTS}

Analysis of glucosinolates and glucosinolate hydrolysis products. Intact $B$. napus meal contained functional myrosinase and four principal glucosinolates including 2-hydroxy-3-butenyl, 3-butenyl, and 4-pentenyl (Table 1). Both autoclaved meal, in which myrosinase was denatured, and intact meal contained all glucosinolates at similar concentrations. Prior addition of water to the intact meal effectively eliminated glucosinolates in the meal designated as hydrolyzed. Glucosinolate analysis of the 'Stonewall' meal confirmed the presence of low glucosinolate concentrations (Table 1).

Glucosinolate hydrolysis products in $\mathrm{CH}_{2} \mathrm{Cl}_{2}$ extracts of wetted meal reflect substrate and enzyme differences among the tissues (Table 2). Intact 'Dwarf Essex' meal produced a number of glucosinolate hydrolysis products in excess of $1 \mu \mathrm{mol} / \mathrm{g}$ of meal including 3-butenyl isothiocyanate, 5-vinyloxazolidine-2-thione, 4pentenyl isothiocyanate, and 3-butenyl epithionitrile. In contrast, the lack of functional myrosinase resulted in very little glucosinolate hydrolysis in autoclaved meal, despite the presence of substantial glucosinolate concentrations. The only glucosinolate hydrolysis product extracted in excess of $1 \mu \mathrm{mol} / \mathrm{g}$ of meal from previously hydrolyzed meal was the relatively nonvolatile 5-vinyloxazolidine-2-thione.

In contrast to meal, aqueous extracts of intact 'Dwarf Essex' were dominated by 5 -vinyloxazolidine-2-thione $(49.5 \mu \mathrm{mol} / \mathrm{g}$ of meal) (Table 3). Other less water-soluble products such as isothiocyanates and nitriles were present at less than $1.5 \mu \mathrm{mol} / \mathrm{g}$ of meal. Extracts from autoclaved 'Dwarf Essex' and intact 'Stonewall' meals also contained 5-vinyloxazolidine-2-thione as the major

TABLE 4. Aphanomyces euteiches f. sp. pisi oospore infection in the presence of $1 \%$ amendments of Brassica napus meal to sand as determined 28 days after inoculation

\begin{tabular}{lccc}
\hline Treatment & $\begin{array}{c}\text { Aphanomyces } \\
\text { rating }(0-4)^{\mathrm{u}}\end{array}$ & $\begin{array}{c}\text { Total plant } \\
\text { weight }^{\mathrm{v}}(\mathrm{g})\end{array}$ & $\begin{array}{c}\text { Root weight } \\
(\mathrm{g})\end{array}$ \\
\hline Without pathogen & & & \\
No meal & 0.0 & $1.53 \mathrm{a}$ & $0.40 \mathrm{a}$ \\
$\quad$ 'Dwarf Essex'w & 0.0 & $1.44 \mathrm{ab}$ & $0.30 \mathrm{~b}$ \\
$\quad$ Autoclaved 'Dwarf Essex'x & 0.0 & $1.34 \mathrm{~b}$ & $0.31 \mathrm{~b}$ \\
Hydrolyzed 'Dwarf Essex'y & 0.0 & $1.43 \mathrm{ab}$ & $0.27 \mathrm{~b}$ \\
$\quad$ 'Stonewall'z & 0.0 & $1.39 \mathrm{ab}$ & $0.33 \mathrm{~b}$ \\
With pathogen & & & \\
No meal & $2.4 \mathrm{a}$ & $1.41 \mathrm{a}$ & $0.32 \mathrm{~b}$ \\
'Dwarf Essex' & $0.0 \mathrm{c}$ & $1.41 \mathrm{a}$ & $0.30 \mathrm{ab}$ \\
Autoclaved 'Dwarf Essex' & $1.1 \mathrm{~b}$ & $1.20 \mathrm{~b}$ & $0.24 \mathrm{bc}$ \\
Hydrolyzed 'Dwarf Essex' & $0.6 \mathrm{bc}$ & $1.36 \mathrm{ab}$ & $0.25 \mathrm{bc}$ \\
'Stonewall' & $2.2 \mathrm{a}$ & $1.24 \mathrm{ab}$ & $0.23 \mathrm{c}$ \\
\hline
\end{tabular}

${ }^{\mathrm{t}}$ Each treatment was performed by adding 100 oospores/g of sand followed in $24 \mathrm{~h}$ by pea seed addition.

u Overall means between inoculated and uninoculated treatments were different $(P<0.05)$. Means within either an inoculated or uninoculated treatment and in the same column followed by the same letter are not statistically different $(P>0.05)$ according to the least significant difference test. Data represent the mean of 16 to 20 replicates per treatment. The experimental data represent the results of a single experiment. The experiment was repeated and similar results were obtained.

$\checkmark$ All reported plant and root weights were fresh weight measurements.

${ }^{w}$ Meal contained glucosinolates and functional myrosinase enzyme responsible for glucosinolate hydrolysis.

x Myrosinase was denatured by autoclaving prior to meal amendment.

y Glucosinolates hydrolyzed and products removed prior to meal amendment.

${ }^{\mathrm{z}}$ Low glucosinolate containing variety. 
product, but at less than $2.0 \mu \mathrm{mol} / \mathrm{g}$ of meal. Autoclaving water extracts obtained from 'Dwarf Essex' meal did not substantially alter concentrations of most observed glucosinolate hydrolysis products (Table 3 ). Therefore, autoclaved agar containing these extracts was, likewise, expected to retain the respective glucosinolate products at bioassay initiation.

Oospore infection in the presence of $B$. napus meal. Intact 'Dwarf Essex' meal with its high concentration of glucosinolates and intact myrosinase completely suppressed oospore infection (Table 4). Autoclaved and hydrolyzed 'Dwarf Essex' meal with reduced glucosinolate concentrations also decreased Aphanomyces root rot compared with the infested control $(P<0.05)$, but not to the extent of the intact meal. 'Stonewall' meal with its low concentration of glucosinolates did not reduce oospore infection as compared with the infested control (Table 4).

The impact of Aphanomyces infestation on pea plant weights was also determined in the presence and absence of various meal amendments. Uninfested meal-treated soils produced total plant weights similar to the uninfested control, except in one treatment (Table 4). Root weights were reduced below that of the respective unamended controls by meal amendment to uninfested treatments and most of the infested treatments. Total plant weights were reduced below that of the respective uninfested and infested controls only with the addition of autoclaved 'Dwarf Essex' meal.

Oospore infection in the presence of aqueous extracts from B. napus meal. Water extracts from intact 'Dwarf Essex' meal almost completely inhibited development of Aphanomyces root rot disease in bioassay experiments (Table 5). Extracts from autoclaved 'Dwarf Essex' meal and extracts from 'Stonewall' meal were ineffective in reducing the disease. Although these two extracts differed from each other statistically, they did not differ $(P>$ 0.05) from the infested control. In contrast to experiments with meal amendments, extracts from autoclaved 'Dwarf Essex' meal showed no toxicity toward oospores.

Root weights were not altered in the presence of water extracts from intact 'Dwarf Essex' meal, but were lowered in the presence of extracts from autoclaved and 'Stonewall' meals (Table 5). Total plant weights were lowered by the addition of aqueous extracts, except the infested treatment amended with an extract from intact 'Dwarf Essex' meal.

TABLE 5. Effect of aqueous extract from Brassica napus meal on oospore infection

\begin{tabular}{|c|c|c|c|}
\hline Treatment ${ }^{\mathrm{u}}$ & $\begin{array}{l}\text { Aphanomyces } \\
\text { rating }(0-4)^{\mathrm{v}}\end{array}$ & $\begin{array}{l}\text { Total plant } \\
\text { weight }^{\mathrm{w}}(\mathrm{g})\end{array}$ & $\begin{array}{l}\text { Root weight } \\
(\mathrm{g})\end{array}$ \\
\hline \multicolumn{4}{|l|}{ Without pathogen } \\
\hline Water & 0.0 & 1.6 & $.42 \mathrm{a}$ \\
\hline 'Dwarf Essex'x & & & $7 \mathrm{ab}$ \\
\hline Autoclaved 'Dwarf Essex'y & 0.0 & & $0.33 \mathrm{bc}$ \\
\hline 'Stonewall'z & 0 & & $0.29 \mathrm{c}$ \\
\hline \multicolumn{4}{|l|}{ With pathogen } \\
\hline Water & $2.6 \mathrm{ab}$ & 1.4 & $0.35 \mathrm{a}$ \\
\hline 'Dwarf Essex' & 0.2 & & $.33 \mathrm{a}$ \\
\hline Autoclaved 'Dwarf Essex' & $3.4 \mathrm{a}$ & $1.17 \mathrm{~b}$ & $0.26 \mathrm{~b}$ \\
\hline 'Ston & $2.5 \mathrm{~b}$ & 1.0 & $0.22 \mathrm{~b}$ \\
\hline \multicolumn{4}{|c|}{$\begin{array}{l}\text { u Each treatment was performed by adding } 100 \text { oospores/g of sand followed } \\
\text { in } 24 \mathrm{~h} \text { by pea seed addition. }\end{array}$} \\
\hline \multicolumn{4}{|c|}{$\begin{array}{l}\text { Overall means between inoculated and uninoculated treatments were differ- } \\
\text { ent }(P<0.05) \text {. Means within either an inoculated or uninoculated treatment } \\
\text { and in the same column followed by the same letter are not statistically } \\
\text { different }(P>0.05) \text { according to the least significant difference test. Data } \\
\text { represent the mean of } 16 \text { to } 20 \text { replicates per treatment. The experimental } \\
\text { data represent the results of a single experiment. The experiment was re- } \\
\text { peated and similar results were obtained. }\end{array}$} \\
\hline \multirow{2}{*}{\multicolumn{4}{|c|}{$\begin{array}{l}{ }^{w} \text { All reported plant and root weights were wet weight measurements. } \\
\text { x Meal contained glucosinolates and functional myrosinase enzyme respon- } \\
\text { sible for glucosinolate hydrolysis. }\end{array}$}} \\
\hline & & & \\
\hline \multicolumn{4}{|c|}{$\begin{array}{l}\text { y Myrosinase was denatured by autoclaving prior to meal amendment. } \\
\text { z Low glucosinolate containing variety. }\end{array}$} \\
\hline
\end{tabular}

Mycelial growth in the presence of water extracts from $B$. napus meal. Water extracts from intact 'Dwarf Essex' meal completely inhibited mycelial growth of Aphanomyces, even at the $50 \%$ dilution (Fig. 1). Extracts from autoclaved and 'Stonewall' meals did not reduce mycelial growth to this extent, but reduced growth significantly compared with the control $(P<0.05)$. The reduction in growth was the same for both of these extracts and was similar with both the original extracts (data not shown) and $50 \%$ dilutions of that extract (Fig. 1).

Mycelial growth in the presence of 5-vinyloxazolidine-2thione. 5-Vinyloxazolidine-2-thione at a concentration equivalent to that measured in aqueous extracts of intact 'Dwarf Essex' meal reduced fungal growth in petri plate assays (Fig. 2). Suppression of mycelial growth was considerably less, however, than observed with aqueous extracts from intact 'Dwarf Essex' meal.

\section{DISCUSSION}

Glucosinolates (I) are hydrolyzed by myrosinase to form unstable aglucone intermediates (II) (Fig. 3). Under neutral conditions, the aglucone undergoes Lossen-type rearrangement to produce the respective isothiocyanate (III). The presence of acidic conditions, specific cofactors, or $\mathrm{Fe}^{2+}$ favors the production of nitriles (IV). The large number of isothiocyanates and nitriles identified in $\mathrm{CH}_{2} \mathrm{Cl}_{2}$ extracts demonstrates the prominence of these hydrolysis products in intact meal (Table 2). Hydrolysis products are absent in $\mathrm{CH}_{2} \mathrm{Cl}_{2}$ extracts of autoclaved meal because myrosinase was no longer functional, not because of reduced glucosinolate concentrations (Table 1). The elimination of glucosinolates in previously hydrolyzed meal (Table 1) explains the lack of isothiocyanates and nitriles in the respective $\mathrm{CH}_{2} \mathrm{Cl}_{2}$ extracts (Table 2). Glucosinolates were hydrolyzed and isothiocyanates and nitriles, thus, dissipated prior to extraction with $\mathrm{CH}_{2} \mathrm{Cl}_{2}$.

As expected, isothiocyanates and nitriles were not prominent products in aqueous extracts (Table 3), because most have low solubilities. Aqueous extracts are, instead, dominated by 5-vinyl-

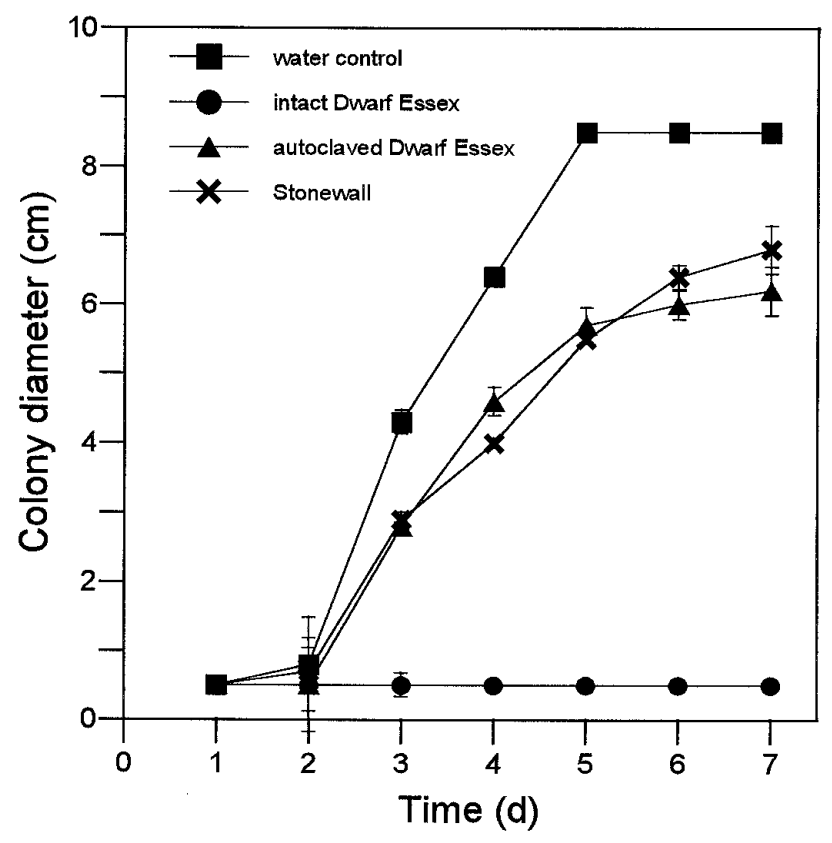

Fig. 1. Aphanomyces mycelial growth in the presence of extracts from defatted Brassica napus meal. Extracts of water-soluble glucosinolate products were obtained at $25 \pm 3^{\circ} \mathrm{C}$ from $30 \mathrm{~g}$ of B. napus meal. A $50 \%$ dilution of the extract was used in place of water for the preparation of a $50 \%$ corn meal agar medium (CMA Y2). After autoclaving the media, discs of the fungus from 5- to 7-day-old colonies were placed in the center of petri plates and radial growth was measured daily on plates incubated for 5 days at $25^{\circ} \mathrm{C}$. 
oxazolidine-2-thione (VI) (Fig. 3), a compound originating from 2-hydroxy-3-butenyl glucosinolate. This glucosinolate, present at high concentrations in intact meal, produces 2-hydroxy-3-butenyl isothiocyanate $(\mathrm{V})$, which spontaneously cyclizes to form the oxazolidinethione (Fig. 3). This intramolecular reaction is typical for glucosinolates possessing a $\beta$-hydroxyl group (24).

Intact 'Dwarf Essex' meal completely inhibited oospore infection in amendment experiments, most likely because of the combined impact of volatile and water-soluble allelochemicals such as isothiocyanates, nitriles, and oxazolidinethiones identified in Table 2. 'Stonewall' meal, with lower glucosinolate concentrations, did not produce these compounds and, correspondingly, did not inhibit oospore infection. The lack of antifungal activity with 'Stonewall' meal provides evidence that decreased oospore infection was not a result of organic carbon addition and a general increase in microbial activity.

The two treated forms of 'Dwarf Essex' meal, hydrolyzed and autoclaved, showed partial inhibition of oospore infection in amendment experiments, most likely because low concentrations of allelochemicals remained within the meal tissues. In hydrolyzed meal, detectable concentrations of 5-vinyloxazolidine-2thione, 3-butenyl isothiocyanate, phenylethyl isothiocyanate, and 5-allyloxazolidine-2-thione were present (Table 2). 3-Butenyl isothiocyanate and phenylethyl isothiocyanate are among the more fungitoxic of the naturally occurring isothiocyanates $(1,25)$.

Autoclaved tissues contained trace concentrations of isothiocyanates and nitriles and a small but measurable amount of 5-vinyloxazolidine-2-thione (Table 2), which could reduce oospore infection. Although high glucosinolate concentrations were present in these tissues, previous research indicates that it is unlikely that glucosinolates themselves altered the ability of oospores to infect the tissues. Kyung and Fleming (18) showed that antibacterial activity of cabbage (B. oleraceae) is destroyed by heating, and Mithen et al. (25) determined that intact glucosinolates do not display significant antifungal activity towards Leptosphaeria

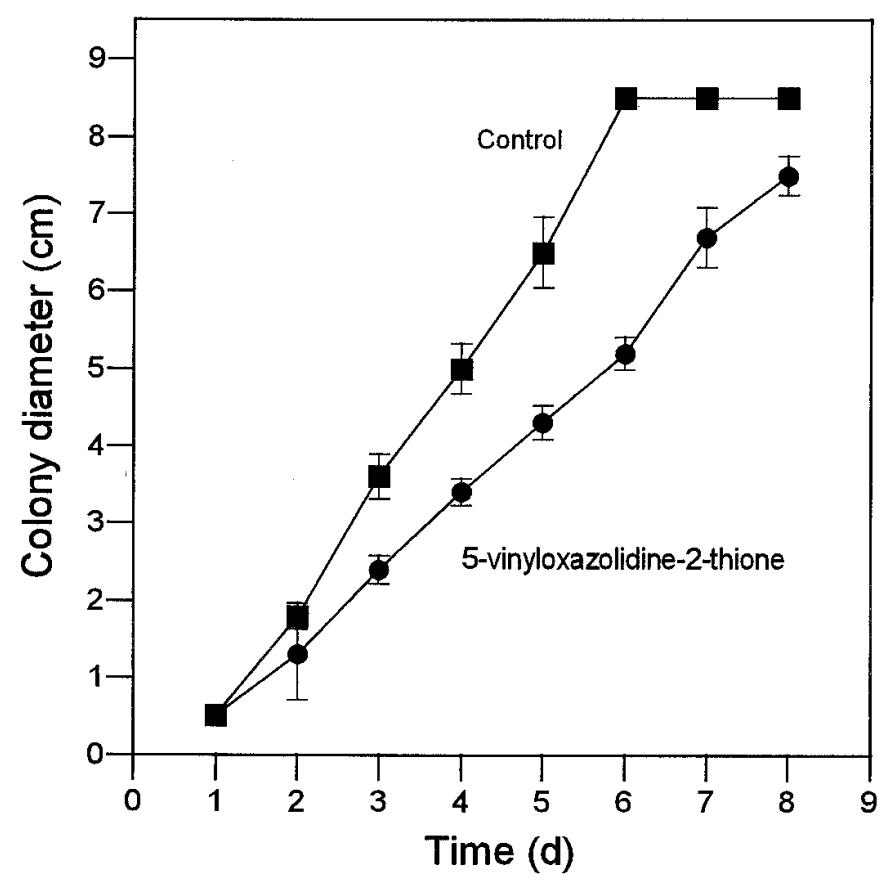

Fig. 2. Inhibition of Aphanomyces mycelial growth by 5-vinyloxazolidine-2thione. 5-Vinyloxazolidine-2-thione was added to $50 \%$ corn meal agar medium (CMA Y2) to achieve a final concentration of $1.48 \mu \mathrm{mol} / \mathrm{cm}^{3}$. A 5mm disc of A. euteiches was placed in the center of the petri plate containing CMA Y2 prepared with 5-vinyloxazolidine-2-thione, and the plates were incubated under lighted conditions at $25^{\circ} \mathrm{C}$. The diameter of the colonies was measured daily and compared with control plates containing CMA Y2 without 5-vinyloxazolidine-2-thione. maculans. However, fungi and bacteria produce enzymes capable of glucosinolate hydrolysis (34), and product formation could have occurred in the rhizosphere of pea plants in this experiment. Alternatively, autoclaved and hydrolyzed meal may contain toxic compounds not identified in our analyses.

The effects observed with meal amendments include the combined impact of a variety of compounds with varying degrees of volatility. Biological effects observed in research with glucosinolate-containing plant tissues are often attributed to volatile compounds $(1,11,13,15,16)$. Our results clearly demonstrated that aqueous extracts from intact 'Dwarf Essex' meal containing less volatile compounds severely reduced oospore infection. Extracts from low glucosinolate 'Stonewall' meal and autoclaved 'Dwarf Essex' meal had no effect on infection. Mycelial growth was altered similarly, with complete inhibition in the presence of water extracts from intact 'Dwarf Essex' meal (Fig. 1). Extracts prepared from autoclaved 'Dwarf Essex' and low glucosinolate 'Stonewall' meals also decreased fungal growth compared with the control, but not to the extent of extracts from intact meal.

These results are consistent with chemical analyses in which intact meal extracts contained substantially higher allelochemical concentrations than autoclaved and 'Stonewall' extracts. The glucosinolate hydrolysis product in highest concentration in all aqueous extracts was 5-vinyloxazolidine-2-thione, with concentrations near $50 \mu \mathrm{mol} / \mathrm{g}$ in extracts from intact meal, but less than 2.0 $\mu \mathrm{mol} / \mathrm{g}$ in autoclaved and 'Stonewall' extracts. Our results showed that 5-vinyloxazolidine-2-thione decreased mycelial growth of $A$. euteiches on petri plates, however, less effectively than aqueous meal extracts, despite the use of equivalent oxazolidinethione concentrations. Thus, toxicity of meal extracts can be only partially explained by the presence of 5-vinyloxazolidine-2-thione.

Beside the well-known ability of 5-vinyloxazolidine-2-thiones to induce goiter of the thyroid gland, general toxicity appears to be relatively low. For example, oxazolidinethiones had little effect on propionic bacteria (32) or Leptosphaeria maculans (25), but, similar to our case, had some effect against Phoma lingam (33). Concentrations of additional glucosinolate degradation products in our aqueous extracts such as 3-butenyl or methylsulfinyl isothiocyanates were relatively low, but, in contrast to studies with pure
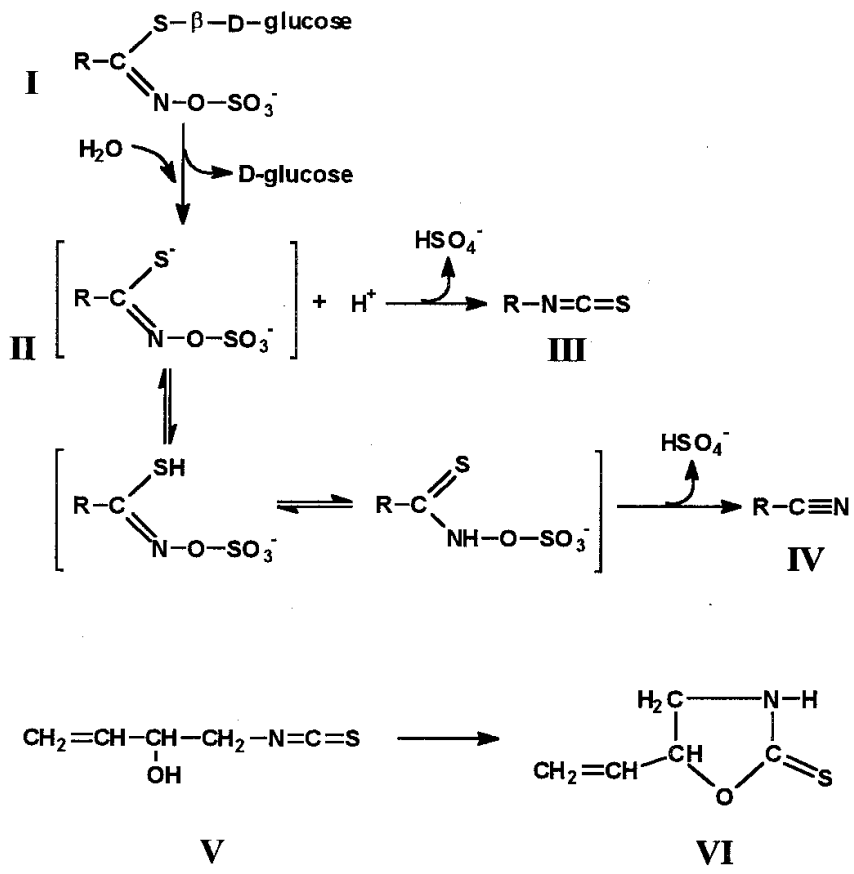

Fig. 3. Glucosinolate hydrolysis products resulting from enzymatic degradation and spontaneous rearrangements. $\mathrm{I}=$ glucosinolate, $\mathrm{II}=$ aglucone, $\mathrm{III}=$ isothiocyanate, IV = nitrile, $\mathrm{V}=2$-hydroxy-3-butenyl isothiocyanate, and VI =5-vinyloxazolidine-2-thione. 
oxazolidinethiones, these compounds may account for the higher activity of the extracts by acting synergistically or in an additive manner with oxazolidinethione.

In addition to effects on $A$. euteiches, meal and aqueous extracts, in some cases, negatively impacted plant growth. Glucosinolate hydrolysis products are indeed phytotoxic (14). Inhibition of plant growth as reflected in lower green tissue or root weights, however, was, in many cases, independent of glucosinolate hydrolysis product concentration in the meal or meal extracts. Even 'Stonewall' meal with low glucosinolate concentrations reduced plant weights. Rapeseed meal contains a high concentrations of phenolics (17), compounds potentially detrimental to crops (23). Commonly cultivated rapeseeds including those with low levels of glucosinolates have similar phenolic concentrations (17), which may partially explain the observed phytotoxicity. Phytotoxicity is, thus, not solely a function of glucosinolate concentrations, and disease suppression with glucosinolate-containing tissues may be possible with minimal plant growth inhibition.

In summary, we demonstrated that toxicity of rapeseed meal or aqueous meal extracts toward A. euteiches strongly correlated with the presence of glucosinolate degradation products. Our results demonstrate that the responsible allelochemicals include not only highly volatile constituents as previously predicted, but low volatility water-soluble compounds that include, but are not limited to, 5-vinyloxazolidine-2-thione.

\section{ACKNOWLEDGMENTS}

Research supported, in part, by USDA CSREES grants 93-34103-8693 and 93-COOP-1-8648, and state and federal funds provided to the Idaho Agricultural Experiment Station.

\section{LITERATURE CITED}

1. Angus, J. F. 1994. Biofumigation: Isothiocyanates released from Brassica roots inhibit growth of the take-all fungus. Plant Soil 162:107-112.

2. Brown, P. D., and Morra, M. J. 1995. Glucosinolate-containing plant tissues as bioherbicides. J. Agric. Food Chem. 43:3070-3074.

3. Brown, P. D., Morra, M. J., and Borek, V. 1994. Gas chromatography of allelochemicals produced during glucosinolate degradation in soil. J. Agric. Food Chem. 42:2029-2034.

4. Chan, M. K. Y., and Close, R. C. 1987. Aphanomyces root rot of peas. 3. Control by the use of cruciferous amendments. N.Z. J. Agric. Res. 30:225-233.

5. Chew, F. S. 1988. Biological effects of glucosinolates. Pages 155-181 in: Biologically Active Natural Products: Potential Use in Agriculture. H. G. Cutler, ed. American Chemical Society, Washington, DC.

6. Daun, J. K., and McGregor, D. J. 1983. Glucosinolate analysis of rapeseed (canola). Method of the Canadian Grain Commission Grain Research Laboratory. Canadian Grain Commission, Agriculture Canada, Winnipeg.

7. Dawson, G. W., Doughty, K. J., Hick, A. J., Pickett, J. A., Pye, B. J., Smart, L. E., and Wadhams, L. J. 1993. Chemical precursors for studying the effects of glucosinolate catabolites on diseases and pests of oilseed rape (Brassica napus) or related plants. Pestic. Sci. 39:271-278.

8. Dhingra, O. D., and Sinclar, J. B. 1985. Basic Plant Pathology Methods. CRC Press, Boca Raton, FL.

9. Drobnica, L., Zemanova, M., Nemec, P., Antos, K., Kristian, P., Stullerova, A., Knoppova, V., and Nemec, P., Jr. 1967. Antifungal activity of isothiocyanates and related compounds. I. Naturally occurring isothiocyanates and their analogues. Appl. Microbiol. 15:701-709.

10. Drobnica, L., Zemanova, M., Nemec, K., Kristian, P., Antos, K., and Hulka, A. 1967. Antifungal activity of isothiocyanates and related compounds. II. Mononuclear aromatic isothiocyanates. Appl. Microbiol. 15:710-717.

11. Gamliel, A., and Stapleton, J. J. 1993. Characterization of antifungal volatile compounds evolved from solarized soil amended with cabbage residues. Phytopathology 83:899-905.

12. Gil, V., and MacLeod, A. J. 1980. Studies on glucosinolate degradation in Lepidium sativum seed extracts. Phytochemistry 19:1369-1374.

13. Greenhalgh, J. R., and Mitchell, N. D. 1976. The involvement of flavour volatiles in the resistance to downy mildew of wild and cultivated forms of Brassica oleracea. New Phytol. 77:391-398.

14. Ju, H.-Y., Bible, B. B., and Chong, C. 1983. Influence of ionic thiocyanate on growth of cabbage, bean, and tobacco. J. Chem. Ecol. 9:12551263.

15. Kirkegaard, J. A., Angus, J. F., Gardner, P. O., and Cresswell, H. P. 1993. Benefits of Brassica break crops in the southeast wheatbelt. Pages 282285 in: Proc. Aust. Agric. Conf., 7th. G. K. McDonald and W. D. Belloti, eds. Australian Society of Agronomy, Adelaide, Australia.

16. Kirkegaard, J. A., Gardner, P. A., Desmarchelier, J. M., and Angus, J. F. 1993. Biofumigation-Using Brassica species to control pests and diseases in horticulture and agriculture. Pages 77-82 in: Proc. Aust. Res. Assembly on Brassicas, 9th. N. Wratten and R. Mailer, eds. New South Wales Department of Agriculture, Wagga Wagga, Australia.

17. Kozlowska, H., Naczk, M., Shahidi, F., and Zadernowski, R. 1990. Phenolic acids and tannins in rapeseed and canola. Pages 193-219 in: Canola and Rapeseed. Production, Chemistry, Nutrition and Processing Technology. F. Shahidi, ed. Van Nostrand Reinhold, New York.

18. Kyung, K. H., and Fleming, H. P. 1994. Antibacterial activity of cabbage juice against lactic acid bacteria. J. Food Sci. 59:125-129.

19. Larsen, P. O. 1981. Glucosinolates. Pages 501-525 in: The Biochemistry of Plants, Vol. 7. Secondary Plant Products. E. E. Conn, ed. Academic Press, New York.

20. Lewis, J. A., and Papavizas, G. C. 1970. Evolution of volatile sulfurcontaining compounds from decomposition of crucifers in soil. Soil Biol. Biochem. 2:239-246.

21. MacLeod, A. J., and Rossiter, J. T. 1986. Isolation and examination of thioglucoside glucohydrolase from seeds of Brassica napus. Phytochemistry 25:1047-1051.

22. Mason-Sedun, W., and Jessop, R. S. 1988. Differential phytotoxicity among species and cultivars of the genus Brassica to wheat. II. Activity and persistence of water-soluble phytotoxins from residues of the genus Brassica. Plant Soil 107:69-80.

23. Mason-Sedun, W., and Jessop, R. S. 1989. Differential phytotoxicity among species and cultivars of the genus Brassica to wheat. III. Effects of environmental factors during growth on the phytotoxicity of residue extracts. Plant Soil 117:93-101.

24. McGregor, D. I., Mullin, W. J., and Fenwick, G. R. 1983. Analytical methodology for determining glucosinolate composition and content. J. Assoc. Off. Anal. Chem. 66:825-849.

25. Mithen, R. F., Lewis, B. G., and Fenwick, G. R. 1986. In vitro activity of glucosinolates and their products against Leptosphaeria maculans. Trans. Br. Mycol. Soc. 87:433-440.

26. Muehlchen, A. M., Rand, R. E., and Parke, J. L. 1990. Evaluation of crucifer green manures for controlling Aphanomyces root rot of peas. Plant Dis. 74:651-654.

27. Owino, P. O., Waudo, S. W., and Sikora, R. A. 1993. Biological control of Meloidogyne javanica in Kenya: Effect of plant residues, benomyl and decomposition products of mustard (Brassica campestris). Nematologica 39:127-134.

28. Papavizas, G. C. 1966. Suppression of Aphanomyces root rot of peas by cruciferous soil amendments. Phytopathology 56:1071-1075.

29. Parke, J. L., Rand, R. E., Joy, A. E., and King, I. B. 1991. Biological control of Pythium damping-off and Aphanomyces root rot of peas by application of Pseudomonas cepacia or P. fluorescens to seed. Plant Dis. 75:987-992.

30. Peterson, C. L., Auld, D. L., and Thompson, J. C. 1983. Experiments with vegetable oil expression. Trans. Amer. Soc. Agric. Eng. 26:12981302.

31. Rice, E. L. 1995. Biological Control of Weeds and Plant Diseases. University of Oklahoma Press, Norman, OK.

32. Rutkowski, A., Bielecka, M., Kornacka, D., Kozlowska, H., and Roezniakowa, B. 1972. Rapeseed meal XX. Influence of toxic compounds of rapeseed meal on the technological properties of propionic acid bacteria. Can. Inst. Food Sci. Technol. J. 5:67-71.

33. Schnug, E., and Ceynowa, J. 1990. Phytopathological aspects of gluosinolates in oilseed rape. J. Agron. Crop Sci. 165:319-328.

34. Underhill, E. W. 1980. Glucosinolates. Pages 493-511 in: Encyclopedia of Plant Physiology. Vol. 8. Secondary Plant Products. E. A. Bell and B. V. Charwood, eds. Springer-Verlag, New York.

35. van Etten, C. H., and Tookey, H. L. 1979. Chemistry and biological effects of glucosinolates. Pages 471-500 in: Herbivores, Their Interaction with Secondary Plant Metabolites. G. A. Rosenthal and D. H. Janzen, eds. Academic Press, New York.

36. Vierheilig, H., and Ocampo, J. A. 1990. Effect of isothiocyanates on germination of spores of G. mosseae. Soil Biol. Biochem. 22:1161-1162. 